\title{
PENINGKATAN KERAGAMAN Grammatophyllum scriptum (L.) Blume ASAL SULAWESI DENGAN IRADIASI SINAR GAMMA
}

\section{Enhancing diversity of Grammatophyllum scriptum (L.) Blume from Sulawesi using Gamma Irradiation}

\author{
Elizabeth Handini ${ }^{1}{ }^{*}$, Popi Aprilianti ${ }^{1}$, Sasanti Widiarsih ${ }^{2}$ \\ ${ }_{1}^{1}$ Pusat Penelitian Konservasi Tumbuhan dan Kebun Raya-LIPI \\ JI. Ir. H. Juanda No. 13 Bogor 16003 \\ ${ }^{2}$ Pusat Aplikasi Isotop dan Radiasi-BATAN \\ Jl. Lebak Bulus Raya No. 49, Jakarta 12440 \\ *Email: lizahandini@gmail.com
}

Diterima/Received: 23 Maret 2020; Disetujui/Accepted: 11 Juli 2020

\begin{abstract}
Grammatophyllum scriptum (L.) Blume or tiger orchid is one of Bogor Botanic Gardens' collections which was collected from Sulawesi. Elongated stem of this species frequently occurred during in vitro propagation. Therefore, gamma irradiation was used in order to obtain mutation of protocorm. The aim of this study was to reduce the length of segment stem using gamma irradiation in order to generate rosette leaf arrangement as a candidate of superior mutant produced. Four doses of gamma irradiation were used viz. $0 \mathrm{~Gy}, 15 \mathrm{~Gy}, 30 \mathrm{~Gy}$, and $45 \mathrm{~Gy}$. Seeds were germinated in various modification media such as, modification of Knudson'C medium (KC and KCA), modification of VW medium, and modification of Hyponex medium. The result showed that VW modification medium gave best media for seeds germination. Subsequently, the protocorms growing in this medium were irradiated to create mutant. Based on data analysis showed that Lethal Dose 50 (LD 50) of protocorm G. scriptum was found in 43.46 Gy and for LD 20 was found in 20.9 Gy. Diverse stem morphology occurred in 15-30 Gy dose irradiation, meanwhile 45 Gy irradiation caused entire protocorms fail to recovery and finally dead.
\end{abstract}

Keywords: Grammatophyllum scriptum, lethal dose, mutation, Vacin and Went medium

\begin{abstract}
Abstrak
Kebun Raya Bogor memiliki koleksi anggrek macan (Grammatophyllum scriptum (L.) Blume) dan salah satu koleksinya berasal dari Sulawesi. Pemanjangan batang jenis ini sering terjadi selama diperbanyak secara in vitro, sehingga diperlukan adanya mutasi protokorm dengan menggunakan sinar gamma. Tujuan dari penelitian ini adalah memperpendek morfologi ruas batang dengan iradiasi gamma, agar didapatkan susunan daun lebih roset, yang nantinya dapat dijadikan sebagai kandidat bibit unggul dari mutan-mutan yang dihasilkan. Iradiasi dilakukan dengan menggunakan dosis 0, 15, 30, dan 45 Gray (Gy). Media yang digunakan untuk menyemai biji adalah modifikasi media Knudson' $\mathrm{C}$ (KC dan KCA), modifikasi VW, dan modifikasi Hyponex. Media VW yang dimodifikasi menunjukkan hasil perkecambahan terbaik dan untuk selanjutnya protokorm yang tumbuh pada media tersebut diiradiasi untuk menghasilkan mutan. Hasil analisis menunjukkan Lethal Dosis (LD) 50 protokorm G. scriptum pada dosis iradiasi 43,46 Gy, sedangkan LD 20 terletak pada dosis iradiasi 20,9 Gy. Keragaman morfologi ruas batang anggrek hasil iradiasi terjadi pada dosis iradiasi 15-30 Gy, sementara dosis iradiasi 45 Gy tidak dapat melewati tahap pemulihan sehingga eksplan mengalami kematian $100 \%$.
\end{abstract}

Kata kunci: Grammatophyllum scriptum, lethal dose, media Vacin dan Went, mutasi 


\section{PENDAHULUAN}

Keanekaragaman anggrek di Indonesia sangat berlimpah, diperkirakan terdapat 5000 jenis anggrek yang ada di Indonesia. Grammatophyllum merupakan marga anggrek tropis yang sangat diminati oleh masyarakat, karena bunganya yang menarik dengan ukuran perbungaan yang besar. Terdapat 12 jenis Grammatophyllum yang tersebar di dunia, salah satunya Grammatophyllum scriptum (L.) Blume (Gambar 1), yang terdistribusi dari Fiji dan Kepulauan Solomon melalui Papua Nugini dan Indonesia sampai ke Filipina (O'Byrne 1994). Anggrek ini merupakan salah satu anggrek terbaik yang memiliki 25-50 kuntum bunga per tangkai, berwarna hijau sampai kuning dengan noktah cokelat, dan musim berbunga yang cukup lama yaitu Januari-Agustus. Selain itu habitusnya tegap dan kuat, sehingga potensial untuk dijadikan tanaman hias (O'Byrne 1994; Wijayani et al. 2007; Sasongko et al. 2016).

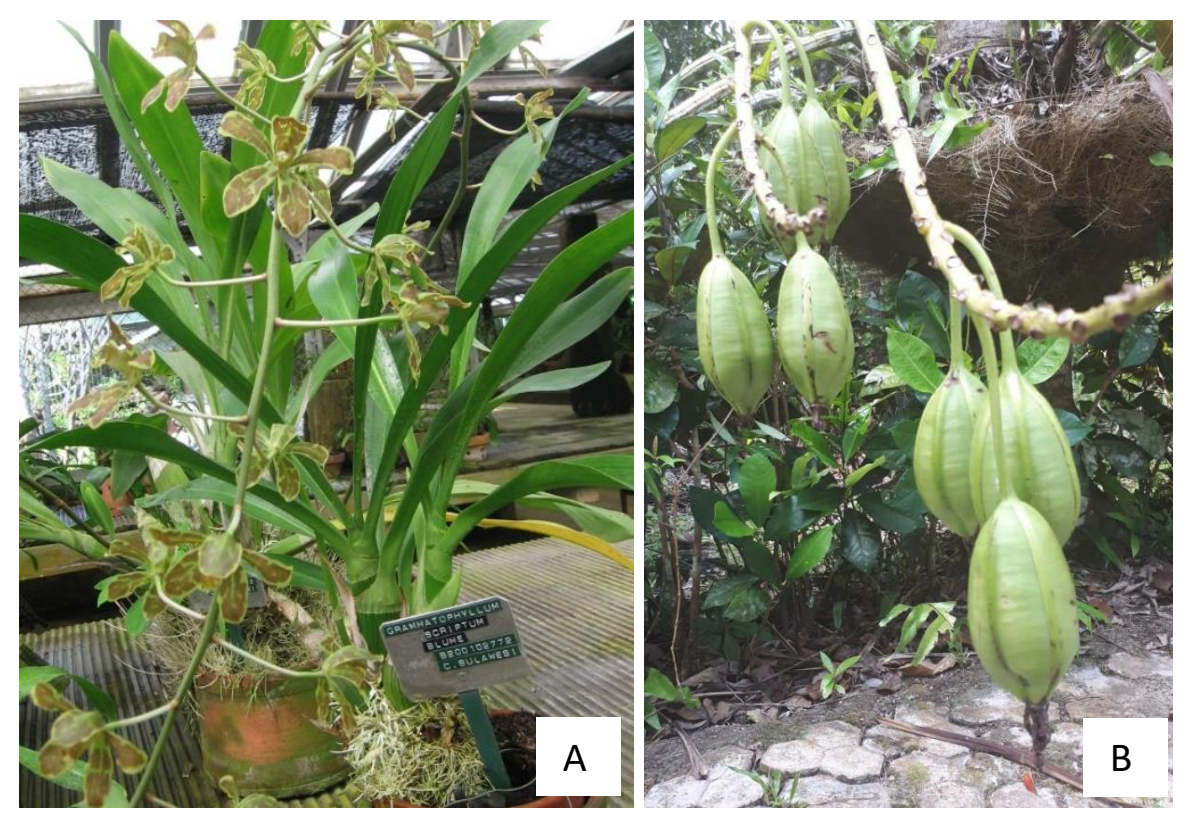

Gambar 1. Grammatophyllum scriptum. A. Tanaman dan bunga; B. Buah

Pusat Penelitian Konservasi Tumbuhan dan Kebun Raya atau dikenal dengan nama Kebun Raya Bogor (KRB) merupakan lembaga konservasi ex situ yang memiliki tugas dan fungsi untuk melakukan upaya konservasi, terutama tumbuhan asli Indonesia. Dari berbagai jenis tumbuhan yang dikoleksi di KRB, pengembangan dan pemanfaatan koleksi dilakukan untuk mengetahui potensi dan peningkatan keragaman genetik tanaman yang ada, termasuk untuk koleksi anggrek G. scriptum. Salah satu koleksi jenis tersebut merupakan hasil kegiatan eksplorasi dari Sulawesi. Selain diperbanyak secara in vitro, anggrek ini juga diiradiasi menggunakan sinar gamma sebagai mutagen fisik dalam rangka meningkatkan keragaman genetik.

Mutasi merupakan perubahan acak yang terjadi tiba-tiba dan secara umum menginduksi perubahan struktur dan komposisi genom, kromosom, atau DNA. Perubahan tersebut dapat diwariskan dalam suatu organisme. Paparan mutagen pada material genetik tanaman, seperti benih, serbuk sari, rimpang, ataupun kalus dapat meningkatkan peluang untuk mendapatkan isolasi bahan genetik yang unik. Mutasi induksi dapat menciptakan variabilitas sifat-sifat yang diwariskan dalam tanaman, baik secara kuantitatif maupun kualitatif. Sinar gamma termasuk radiasi pengion yang dapat bertindak langsung pada molekul komponen selular atau secara tidak langsung pada molekul air, sehingga menyebabkan adanya sifat radikal dari air (Gaswanto et al. 2016).

Variabilitas genetik merupakan prasyarat paling penting untuk keberhasilan program pemuliaan tanaman, terutama pada tanaman hias, karena menyediakan spektrum varian fenotipik yang lebih luas untuk seleksi (Hayati et al. 2016). Pemuliaan mutasi telah berkontribusi terhadap perbaikan tanaman pertanian dan tanaman hias. 
Laporan Program Gabungan FAO/ IAEA (2009) dalam Xo \& Luan (2017) menyebutkan bahwa, teknik nuklir di bidang pertanian telah ada 3100 varietas mutan resmi yang dihasilkan dari 170 jenis tanaman berbeda dari lebih 60 negara. Di antara varietas mutan tersebut, $90 \%$ dihasilkan dengan menggunakan teknik iradiasi. Beberapa varietas bunga baru dengan nilai komersial tinggi, seperti krisan, anturium, Curcuma alismatifolia Gagnep., dan lili, telah dihasilkan dari aplikasi sinar gamma. Sementara sampai saat ini baru ada mutan anggrek Dendrobium "Sonia" yang dihasilkan oleh Agensi Nuklear Malaysia (Ariffin et al. 2010).

Keragaman genetik dibutuhkan sebagai bahan untuk seleksi bibit unggul. Teknik iradiasi sinar gamma dalam kombinasi dengan metode kultur jaringan telah terbukti bermanfaat dalam menghasilkan keragaman tersebut. Pengamatan hasil mutasi induksi pada tanaman hias dapat dilakukan dengan melihat karakter bunga yang dihasilkan, meliputi warna, ukuran, morfologi, dan aroma. Mutasi induksi pada karakter daun, memperlihatkan perubahan pada bentuk, ukuran, dan pigmentasi daun. Perubahan habitus tanaman hasil mutasi induksi juga dapat dilihat pada kekompakan, cara memanjat tanaman, dan percabangan yang dihasilkan. Perubahan sifat fisiologis tanaman hasil mutasi dapat terjadi pada reaksi fotoperiodik, masa berbunga yang lebih awal, kebebasan berbunga, serta kualitas ketahanan seperti toleransi saat melawan cekaman faktor abiotik dan biotik (Schum 2003).

Iradiasi sinar gamma yang dilakukan pada G. scriptum diharapkan memberikan keragaman genetik, yang nantinya dapat digunakan untuk perbaikan sifat ataupun menghasilkan varietas baru yang lebih baik. Oleh karena itu, tujuan dari penelitian ini adalah untuk memperpendek morfologi ruas batang $G$. scriptum agar susunan daunnya dapat berbentuk lebih roset. Hasil penelitian diharapkan akan mendapatkan mutan yang mempunyai keragaan (morfologi) yang lebih baik sebagai tanaman hias bunga yang mempunyai nilai komersial tinggi.

\section{BAHAN DAN METODE}

\section{Lokasi dan waktu}

Iradiasi protokorm G. scriptum dilakukan di Pusat Aplikasi Isotop dan Radiasi - Badan Tenaga
Nuklir Nasional (PAIR-BATAN), pada bulan Juni 2019 dalam rangka sinergi penelitian antara LIPI dengan BATAN. Setelah diiradiasi, penelitian dilanjutkan di Pusat Penelitian Konservasi Tumbuhan dan Kebun Raya (P2KTKR) sampai dengan Februari 2020.

\section{Bahan dan alat}

Bahan yang diiradiasi adalah protokorm G. scriptum yang berumur delapan minggu setelah disemai. Biji anggrek merupakan koleksi P2KTKR yang berasal dari Sulawesi. Biji disemai pada empat jenis media yaitu, 1). Vacin dan Went (VW) yang dimodifikasi dengan penambahan ekstrak taoge $100 \mathrm{~g} \mathrm{~L}^{-1}$, tomat $100 \mathrm{~g} \mathrm{~L}^{-1}$ dan air kelapa $150 \mathrm{ml} \mathrm{L}^{-1}$ dan arang aktif $1 \mathrm{~g} \mathrm{~L}^{-1}$ (media VWS); 2). media Knudson $C$ yang dimodifikasi dengan penambahan unsur mikro (media KCA); 3). media Hyponex yang dimodifikasi dengan penambahan pepton $2 \mathrm{~g} \mathrm{~L}^{-1}$, kentang $40 \mathrm{~g} \mathrm{~L}^{-1}$, arang aktif $1 \mathrm{~g} \mathrm{~L}^{-1}$ (media HS); dan 4). media Knudson $C$ yang dimodifikasi dengan penambahan ekstrak taoge $150 \mathrm{~g} \mathrm{~L}^{-1}$, air kelapa 150 $\mathrm{ml} \mathrm{L}^{-1}$, dan arang aktif $1 \mathrm{~g} \mathrm{~L}^{-1}$ (Media KC). Gula pasir ditambahkan ke dalam media-media tersebut sebanyak $15 \mathrm{~g} \mathrm{~L} \mathrm{~L}^{-1}$ sebagai sumber karbon, sedangkan sebagai bahan pemadat ditambahkan agar sebanyak $7 \mathrm{~g} \mathrm{~L}^{-1}$. $\mathrm{pH}$ medium diatur pada 5,6. Protokorm G. scriptum diiradiasi dengan menggunakan elemen radioaktif Cobalt-60 (Hazekamp 2016) dan disubkultur hingga empat kali (M1V4).

\section{Tahapan pelaksanaan/rancangan penelitian}

\section{Pembentukan protokorm G. scriptum}

Biji anggrek $G$. scriptum didapatkan dari buah matang dan pecah. Protokol penyemaian biji dilakukan dengan metode yang dilakukan oleh Puspitaningtyas \& Handini (2014). Biji direndam dalam air suling steril $50 \mathrm{ml}$ yang telah diberi Tween 80 sebanyak tiga tetes. Larutan berisi biji tersebut divakum selama satu jam, kemudian biji direndam dalam $50 \mathrm{ml}$ larutan natrium hipoklorit komersial 10\% dan 5\% yang telah diberi Tween 80 sebanyak tiga tetes, masing-masing selama 10 dan lima menit. Setelah perendaman, biji dibilas dengan menggunakan air suling steril sebanyak tiga kali. Biji kemudian disebar dalam empat jenis media perkecambahan dengan menggunakan pipet tetes. Biji berkecambah dan membentuk protokorm yang akan dijadikan sebagai bahan untuk diiradiasi. 


\section{Iradiasi protokorm dengan sinar gamma}

Perlakuan iradiasi menggunakan empat dosis iradiasi, yaitu $0 \mathrm{~Gy}, 15 \mathrm{~Gy}, 30 \mathrm{~Gy}$, dan $45 \mathrm{~Gy}$. Masing-masing dosis diulang enam kali dengan 10 protokorm pada setiap ulangannya. Setelah proses iradiasi, protokorm ditanam di media subkultur baru (VWS) untuk pertumbuhan regenerasi (Dehgahi \& Joniyasa 2017), yaitu tahap M1V1 (subkultur yang dilakukan pertama kali setelah perlakuan iradiasi) dan kegiatan subkultur dilakukan sampai dengan M1V2. Botol kultur disimpan dalam ruangan dengan suhu $25 \pm 2^{\circ} \mathrm{C}$ dan fotoperiodisitas 12 jam/hari serta intensitas cahaya 40 watt.

\section{Analisis data}

Analisis data yang dilakukan adalah menentukan dosis iradiasi yang menimbulkan kematian 20\% protokorm atau Lethal Dosis (LD 20) dan LD 50 dengan menggunakan software Curve Expert-32. Pengamatan dilakukan terhadap persentase perkecambahan biji $G$. scriptum untuk menentukan media semai yang memberikan pertumbuhan terbaik. Selain itu, pengamatan dilakukan juga terhadap tinggi tanaman dan jumlah daun yang dihasilkan oleh eksplan selama masa pengamatan setelah perlakuan iradiasi. Pengamatan terhadap karakter tanaman, jumlah akar, dan jumlah protokorm juga dilakukan untuk melihat pengaruh iradiasi sinar gamma. Hasil pengamatan dianalisis menggunakan aplikasi SAS versi 9.00 , yang dilanjutkan dengan uji beda nyata menggunakan uji LSD (Least Significance Different)/Uji BNT (Beda Nyata Terkecil) dan uji Dunnett, untuk mencari beda nyata terhadap perlakuan kontrol.

\section{HASIL DAN PEMBAHASAN}

\section{Perkecambahan biji G. scriptum sebagai bahan iradiasi}

Protokorm mulai tumbuh dalam waktu tiga minggu setelah semai. Protokorm berbentuk bulatmelonjong dengan beberapa akar rambut pada bagian dasar dan tunas meristem pada bagian atas (Chang et al. 2005). Hasil uji viabilitas biji menunjukkan persentase yang tidak berbeda nyata antar media semai VWS $(29,47 \%)$, KCA $(32,29 \%)$, HS $(30,88 \%)$, dan KC $(33,22 \%)$. Namun demikian, pengamatan secara visual memperlihatkan bahwa akar rambut/rizoid (absorbing hairs) yang berfungsi menyerap makanan paling banyak terbentuk pada protokorm yang disemai pada media VWS (Gambar 2).

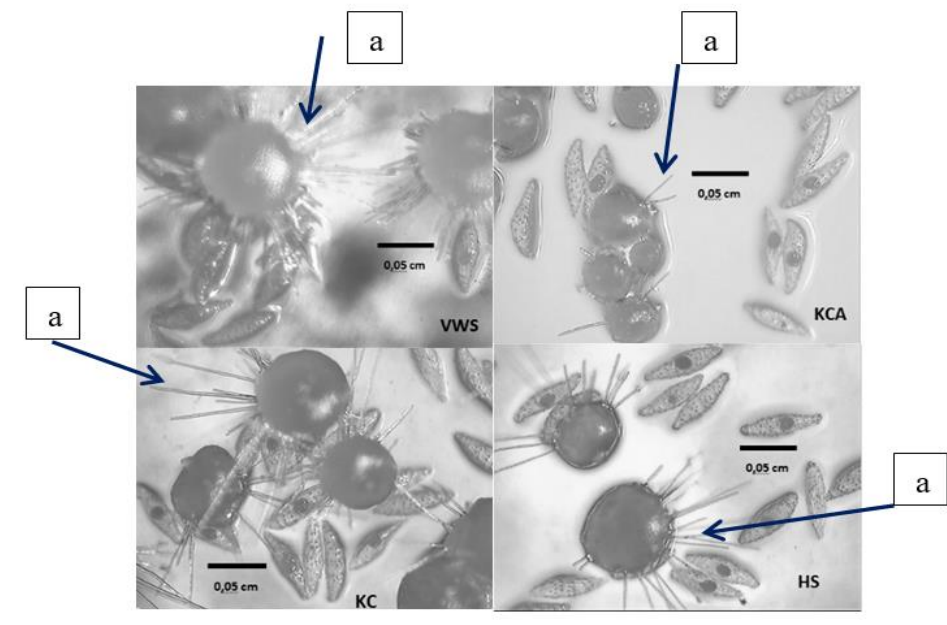

Gambar 2. Perawakan protokorm berumur 3 minggu setelah semai dari masing-masing media semai (VWS, KCA, KC, dan HS) memperlihatkan banyak akar rambut (a) yang bervariasi pada masingmasing media semai, dan yang paling lebat pada media VWS.
Berdasarkan hal tersebut, media subkultur yang digunakan selanjutnya untuk protokorm yang sudah diiradiasi menggunakan media VWS. Media VWS merupakan media Vacin and Went (VW) yang dimodifikasi dengan penggunaan air kelapa, toge, dan tomat yang telah banyak digunakan pada jenis Grammatophyllum lainnya, seperti G. speciosum
Blume dimana hasilnya memberikan pertumbuhan protokorm yang cukup baik (Aprilianti et al. 2018). Hasil penelitian yang dilakukan oleh Utami et al. (2015) pada Paphiopedilum liemianum (Fowlie) K.Karas. \& K.Saito memperlihatkan penggunaan medium VW yang dimodifikasi dengan air kelapa memberikan respon pertumbuhan yang sangat baik 
pada tahap protokorm menjadi seedling (tahapan saat eksplan sudah memiliki dua atau lebih daun). Hal ini disebabkan oleh kandungan dalam air kelapa (karbohidrat, vitamin, asam amino, asam organik, ion organik, dan enzim) yang berperan penting untuk perkembangan sel. Pemilihan media yang optimal sangat penting untuk pertumbuhan protokorm selanjutnya.

\section{Tahap iradiasi}

Protokorm dipilih sebagai bahan iradiasi karena berukuran kecil. Semakin kecil bahan tanam yang diiradiasi akan semakin mudah untuk mendapatkan mutan yang solid. Perlakuan iradiasi dilakukan terhadap protokorm anggrek yang berusia delapan minggu setelah semai. Setelah proses iradiasi, protokorm dipindahkan ke media VWS yang baru (subkultur tahap M1V1).

Hasil penelitian iradiasi protokorm G. scriptum memperlihatkan bahwa dosis yang menimbulkan kematian 20\% (LD 20) pada protokorm sebesar 20,9 Gy, sementara dosis yang menimbulkan kematian 50\% (LD 50) adalah 43,46 Gy (Gambar 3). Penelitian yang dilakukan terhadap Dendrobium hibrid yang diiradiasi dengan mengunakan sinar gamma juga menunjukkan bahwa LD 50 pada anggrek tersebut sebesar $43 \mathrm{~Gy}$ (Dehgahi \& Joniyasa 2017). Penelitian lain yang dilakukan oleh Handini (2019) pada anggrek D. macrophyllum A.Rich. yang diiradiasi dengan sinar gamma juga menunjukkan bahwa LD 50 yang diberikan tidak berbeda jauh dengan anggrek G. scriptum, yaitu sekitar 48,42 Gy.

Mutasi fisik dalam bentuk iradiasi sinar gamma memberikan hasil yang berbeda untuk setiap jenis tumbuhan. Respon yang diberikan bersifat spesifik pada tingkat jenis dan setiap jenis tanaman akan memiliki tingkat radiosensitivitas yang berbeda. Dosis iradiasi yang efektif biasanya sekitar LD 50, atau sedikit di bawah LD 50. Pada taraf dosis ini memungkinkan jaringan tanaman untuk dapat pulih dari kerusakan, walaupun kurang dari frekuensi mutasi. Oleh karena itu, LD 30 dan LD 20 umumnya dapat digunakan sebagai dosis mutagen yang optimal (Hayati et al. 2016). Kerusakan fisiologis akibat iradiasi dapat berupa kematian sel, terhambatnya pembelahan sel, melambatnya kecepatan pertumbuhan tanaman, peningkatan frekuensi pembentukan jaringan tanaman, menurunnya kapasitas bereproduksi tanaman, termasuk menurunnya sterilitas tanaman. Kerusakan fisiologis ini hanya terjadi pada generasi pertama dari populasi tanaman yang diiradiasi (M1) (Surya \& Suranto 2006; Suwarno et al. 2013).

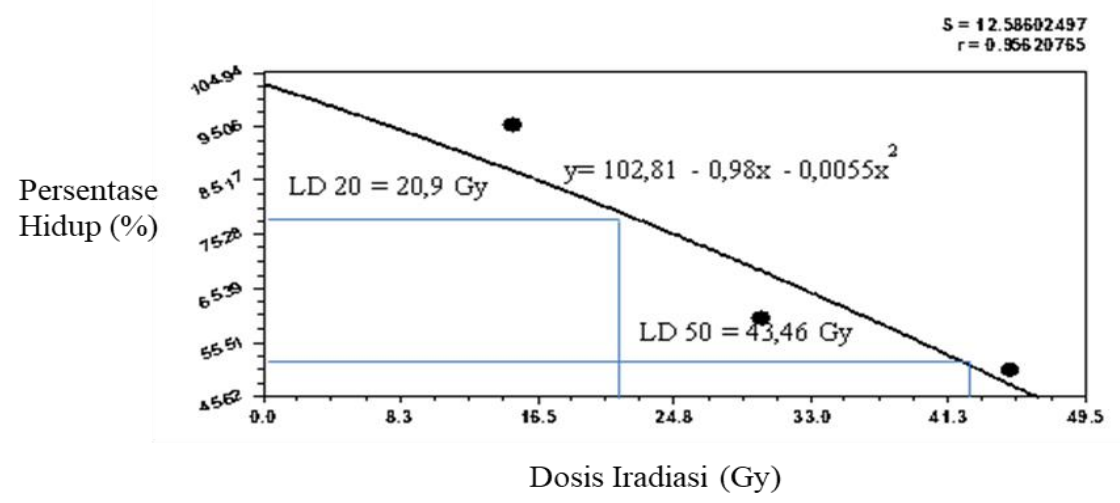

Gambar 3. Grafik penurunan persentase hidup pada protokorm Grammatophyllum scriptum akibat perlakuan iradiasi dosis 0-45 Gy pada 8 MSP (Minggu Setelah Perlakuan).

Pengamatan pertumbuhan dan perkembangan protokorm hasil perlakuan iradiasi menunjukkan kematian protokorm terjadi pada dosis $45 \mathrm{~Gy}$. Hal ini disebabkan protokorm mengalami nekrosis, dan kemudian mengalami kematian pada umur delapan minggu setelah diiradiasi. Persentase hidup protokom semakin menurun sejalan dengan meningkatnya dosis iradiasi yang diberikan (Zanzibar et al. 2015). Pernyataan yang sama juga disampaikan oleh Tokuhara \& Mii (2001) yang mengatakan bahwa frekuensi kematian protokorm akan bertambah seiring dengan meningkatnya ion sinar iradiasi yang diserap oleh eksplan, dalam hal ini protokorm.

Protokorm dengan dosis iradiasi 0-30 Gy masih memperlihatkan adanya pertumbuhan. 
Berdasarkan hasil Analisis Sidik Ragam menunjukkan beda nyata antar perlakuan pada tinggi tanaman, jumlah daun, akar, dan protokorm yang terbentuk (Gambar 4.). Semakin meningkat dosis iradiasi maka tinggi tanaman, jumlah daun, dan jumlah akar semakin berkurang. Hal ini disebabkan oleh dosis iradiasi yang tinggi, yang akan mengurangi jumlah zat pengatur tumbuh endogen yang ada di dalam protokorm (Afrasiab \& lqbal 2010). Selain itu, dosis iradiasi yang tinggi menyebabkan mutasi acak pada tanaman sehingga terjadi kerusakan fisiologis dalam metabolisme perkembangan sel dan mempengaruhi sistem meristem sel tumbuhan, hingga dapat mematikan tanaman (Lestari et al. 2018). Lebih jauh lagi, iradiasi sinar gamma dengan dosis yang tinggi akan mengganggu proses sintesis protein, keseimbangan hormon, dan pertukaran gas pada daun (Borzouei et al. 2010). Hasil penelitian ini sejalan dengan penelitian iradiasi yang dilakukan terhadap Dendrobium sylvanum (Rchb.f.) M.A.Clem. \& D.L.Jones, bahwa dosis $45 \mathrm{~Gy}$ merupakan salah satu dosis inhibitor yang menurunkan pertumbuhan dan perkembangan planlet secara signifikan (Lestari et al. 2018).

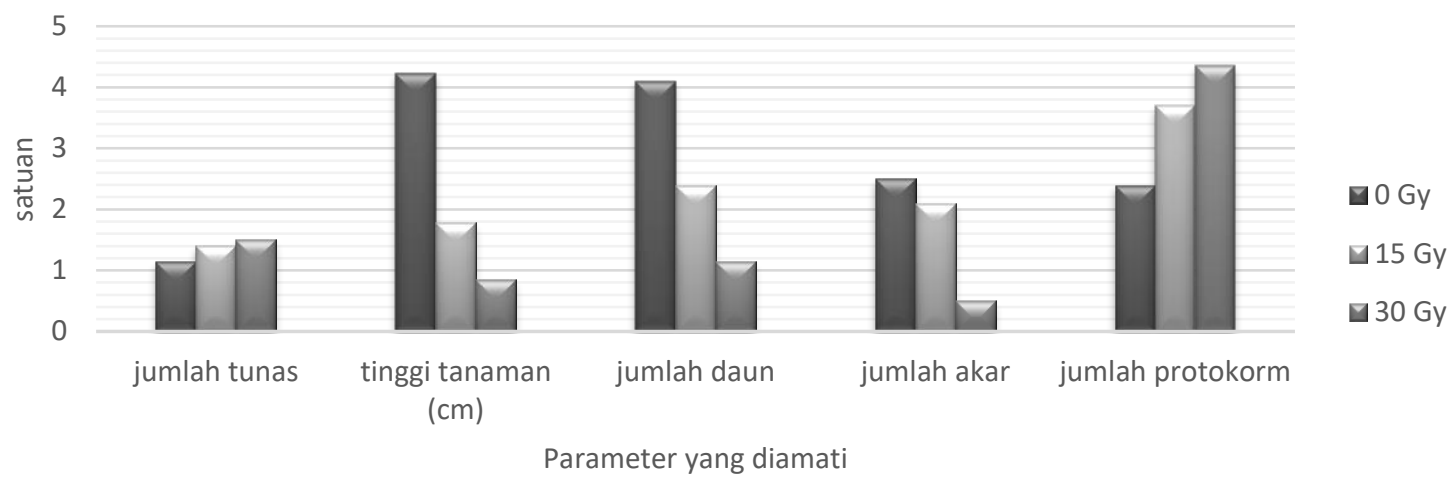

Gambar 4. Efek iradiasi pada pertumbuhan protokorm Grammatophyllum scriptum dengan perlakuan dosis iradiasi 0-30 Gy pada 12 MSP

Tanaman yang paling tinggi serta jumlah daun dan akar paling banyak diperlihatkan oleh tanaman kontrol (Gambar 4). Hal ini menunjukkan iradiasi dengan dosis $15 \mathrm{~Gy}$ dan $30 \mathrm{~Gy}$ menurunkan pertumbuhan dan perkembangan protokorm. Sedikitnya jumlah daun dan akar yang dihasilkan oleh tanaman yang diiradiasi, dipengaruhi oleh perubahan pada tanaman akibat iradiasi sinar gamma, sehingga mempengaruhi laju pembentukan dan pertumbuhan daun dan akar (Lestari et al. 2018).

Terjadi penurunan tinggi tanaman yang diiradiasi dengan dosis 15 Gy dan 30 Gy dibandingkan dengan kontrol. Meskipun demikian, tinggi tanaman yang dihasilkan dari iradiasi dengan dosis 15 Gy masih lebih tinggi dibandingkan dengan dosis $30 \mathrm{~Gy}$. Dosis iradiasi dalam jumlah rendah (15 Gy) masih memiliki efek menstimulasi hormon pertumbuhan, pembelahan sel, dan pertumbuhan tanaman dari pada dosis iradiasi $30 \mathrm{~Gy}$. Dosis iradiasi yang tinggi berdampak buruk terhadap pertumbuhan vegetatif (Kovalchuk et al. 2003, 2004).
Jumlah daun dan akar pada tanaman dengan dosis iradiasi 15 Gy memperlihatkan adanya korelasi kuat, yaitu semakin meningkat dosis iradiasi, jumlah daun dan akar semakin menurun. Di lain sisi, pemberian perlakuan iradiasi meningkatkan jumlah protokorm yang dihasilkan. Jumlah protokorm dengan dosis iradiasi $30 \mathrm{~Gy}$ berbeda nyata dengan tanaman kontrol (Gambar 5.). Hal ini memperlihatkan bahwa dosis iradiasi yang tinggi akan menstimulasi pembentukan protokorm, namun dengan ukuran yang lebih kecil dan disertai dengan penurunan pertumbuhan tanaman.

Hasil uji Dunnet pada pertumbuhan protokorm G. scriptum umur 12 minggu setelah perlakuan (MSP) memperjelas bahwa ada beda nyata antara perlakuan dosis iradiasi 15 Gy dan 30 Gy dengan kontrol, yang terjadi pada parameter tinggi tanaman dan jumlah akar, sedangkan beda nyata dengan kontrol pada parameter jumlah daun hanya terjadi pada dosis iradiasi $30 \mathrm{~Gy}$ saja (Tabel 1). 
Tabel 1. Analisis uji Dunnet pada pertumbuhan protokorm G. scriptum dengan perlakuan dosis iradiasi 0-30 Gy pada 12 MSP

\begin{tabular}{cccccc}
\hline $\begin{array}{c}\text { Perbedaan antar } \\
\text { perlakuan (Gy) }\end{array}$ & $\begin{array}{c}\text { Jumlah } \\
\text { tunas }\end{array}$ & $\begin{array}{c}\text { Tinggi tanaman } \\
(\mathbf{c m})\end{array}$ & $\begin{array}{c}\text { Jumlah } \\
\text { daun }\end{array}$ & $\begin{array}{c}\text { Jumlah } \\
\text { akar }\end{array}$ & $\begin{array}{c}\text { Jumlah } \\
\text { protokorm }\end{array}$ \\
\hline 0 dan 15 & $0,25^{\text {tn }}$ & $-2,45^{* *}$ & $-1,70^{\text {tn }}$ & $-0.40^{* *}$ & $1,30^{\text {tn }}$ \\
0 dan 30 & $0,35^{\text {tn }}$ & $-3,38^{* *}$ & $-2,95^{* *}$ & $-2,00^{* *}$ & $1,95^{\text {tn }}$ \\
\hline
\end{tabular}

Keterangan : ${ }^{* *}$ berbeda nyata dibandingkan kontrol pada taraf $5 \%$ berdasarkan uji $\mathrm{F}$ dan $\mathrm{BNT} ;{ }^{\mathrm{tn}}=$ tidak berbeda nyata dibandingkan kontrol berdasarkan uji F dan BNT.

- (tanda minus) ada penurunan angka dalam selisih antara kontrol dengan perlakuan

Pengamatan hingga 18 MSP pada dosis iradiasi $15 \mathrm{~Gy}$, tinggi tanaman menurun secara signifikan, namun tidak disertai dengan penurunan jumlah daun (Tabel 1). Tanaman dengan dosis iradiasi 15 Gy menghasilkan karakter vegetatif yang lebih baik dibandingkan dengan tanaman kontrol. Karakter tanaman dengan susunan daun lebih roset merupakan karakter yang diinginkan. Pada dosis iradiasi 15 Gy ini telah didapatkan karakter yang lebih roset sehingga berpeluang besar untuk mendapatkan tanaman mutan dengan karakter berbeda dengan induknya. Hasil penelitian yang didapatkan ini sesuai dengan hasil penelitian Wang et al. (2017), mengenai efek sinar gamma pada Sophora davidii (Franch.) Pavol. yang menyebabkan tinggi tanaman mengalami penurunan secara konstan, seiring dengan meningkatnya dosis iradiasi.

Pertumbuhan akar G. scriptum pada dosis iradiasi 15 Gy juga tidak berbeda jauh dengan tanaman kontrol. Hal ini mengindikasikan bahwa tanaman tersebut akan mampu meningkatkan daya hidup untuk pertumbuhan selanjutnya. Sementara pada dosis iradiasi $30 \mathrm{~Gy}$, jumlah akar sangat sedikit dan dikhawatirkan akan memperlambat pertumbuhan tanaman selanjutnya (Gambar 5).

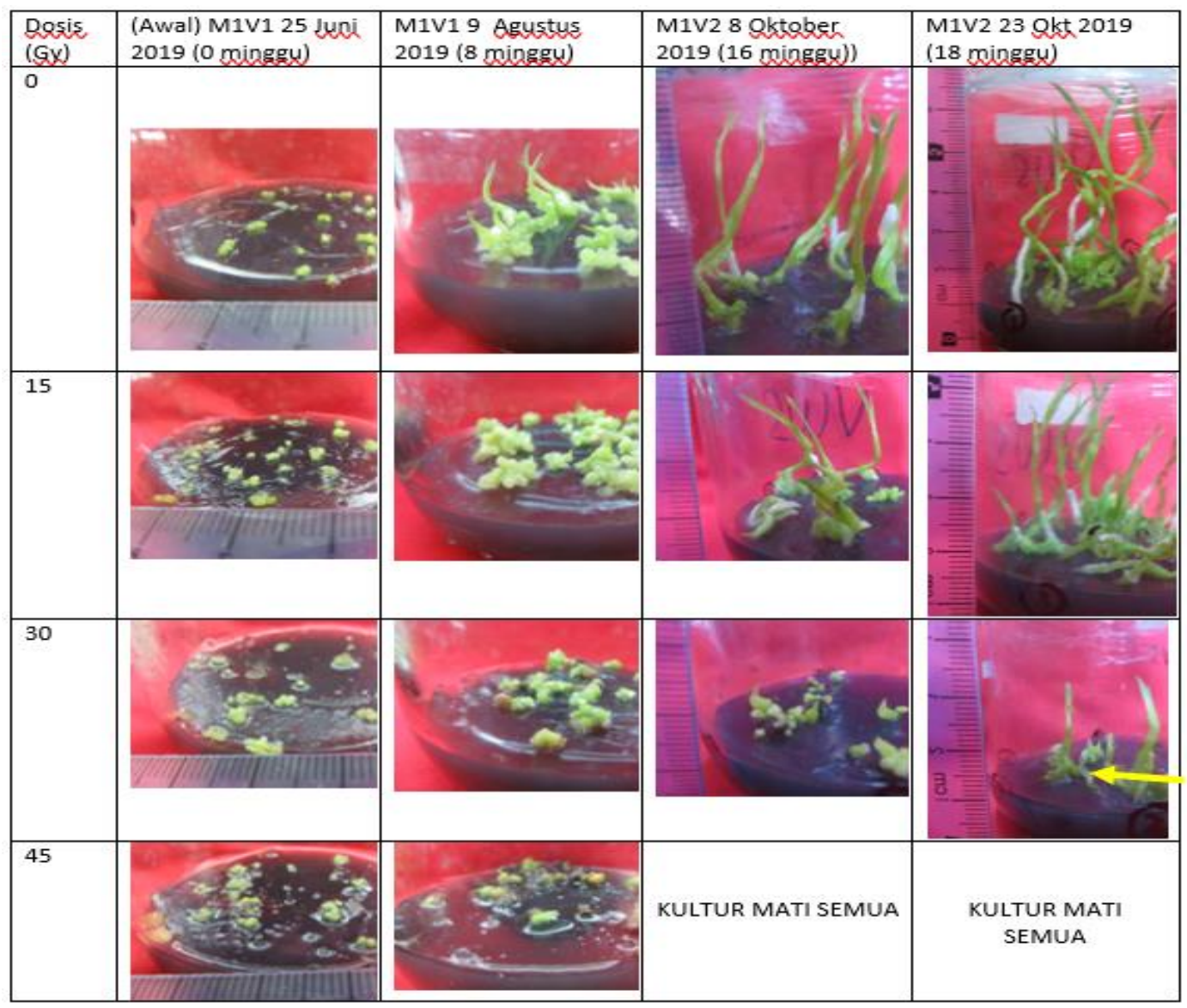

Gambar 5. Keragaan Grammatophyllum scriptum dengan perlakuan dosis iradiasi 0-45 Gy pada 0-18 MSP. Anak panah kuning menunjukkan akar yang sedikit pada dosis $30 \mathrm{~Gy}$ 
Permasalahan utama dalam penelitian ini adalah karakter tanaman $G$. scriptum dengan dosis iradiasi $0 \mathrm{~Gy}$ (kontrol) hingga $32 \mathrm{MSP}$, dimana pada awalnya tanaman tersebut memanjangkan batang, dengan menumbuhkan daun dan akar pada bagian ruas-ruas batang. Hal tersebut mempersulit kegiatan subkultur, sehingga dilakukan pemangkasan batang pada setiap kegiatan subkultur agar tanaman yang terbentuk tidak terlalu tinggi.

Salah satu karakter baru yang menjadi target kegiatan iradiasi ini adalah ruas batang memendek dan susunan daun roset, sehingga mempermudah dan mempercepat proses pertumbuhan tanaman hingga siap aklimatisasi, serta memperbaiki keragaan tanaman. Karakter yang diinginkan tersebut mulai terlihat pada beberapa tanaman hasil iradiasi pada dosis 15 Gy. Sementara pada tanaman dengan dosis iradiasi $30 \mathrm{~Gy}$, banyak memunculkan tanaman abnormal, seperti batang berdiameter kecil dan memanjang, dengan daun mengecil atau banyak muncul tunas baru (Gambar 6). Hal ini mirip dengan hasil penelitian Aloysius et al. (2017) tentang perlakuan iradiasi sinar $X$ pada Spathoglottis plicata Blume yang menyebabkan kegagalan pembelahan sel, dan menyebabkan primordia daun yang tumbuh hanya melalui pemanjangan sel. Tanpa adanya pembelahan sel, pertumbuhan daun menjadi abnormal, sehingga daun dan batang menjadi kerdil.

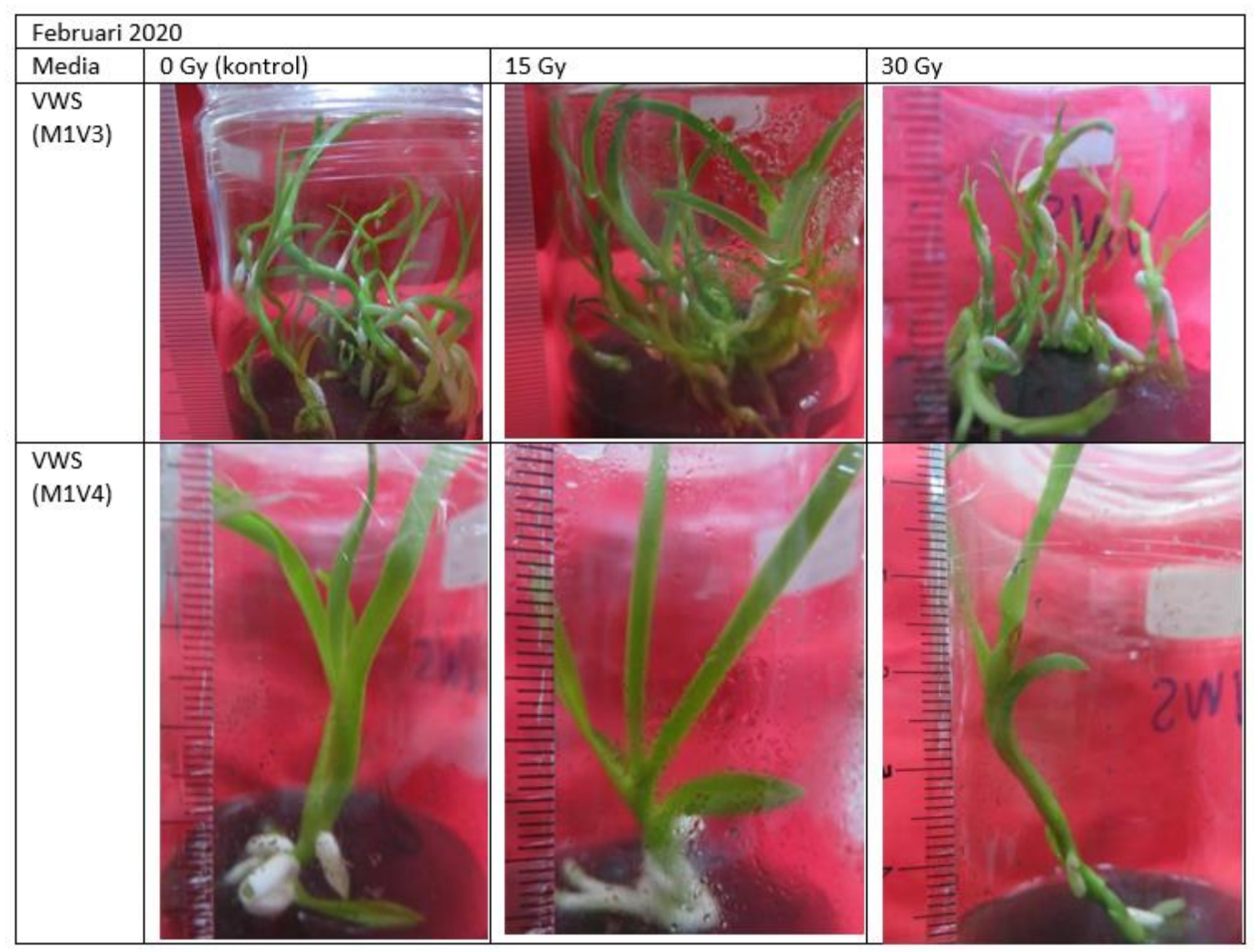

Gambar 6. Keragaan G. scriptum dengan perlakuan dosis iradiasi 0-30 Gy pada 32 MSP

Pengamatan selanjutnya lebih ditekankan pada dosis iradiasi 15 Gy untuk menyeleksi mutanmutan yang mempunyai kriteria yang lebih baik dari tanaman kontrol, yaitu mempunyai ruas batang lebih pendek sehingga susunan daun menjadi roset. Penyaringan (screening) untuk fenotipe unik hasil pemuliaan, khususnya melalui iradiasi merupakan tahapan yang penting untuk pengembangan tanaman hias kultivar baru. Seperti pada penelitian iradiasi planlet Celosia cristata L., pada dosis iradiasi 50 Gy telah memperpendek ruas batang dan menghasilkan karakter daun keriting/ bergelombang. Sementara dosis iradiasi $25 \mathrm{~Gy}$ menghasilkan planlet dengan daun terbelah (Hayati et al. 2016). 


\section{KESIMPULAN DAN SARAN}

Media VW yang dimodifikasi (media VWS) dapat meningkatkan pertumbuhan protokorm Grammatophyllum scriptum. Perlakuan iradiasi protokorm G. scriptum sinar gamma dengan dosis 15 Gy menghasilkan tanaman calon mutan dengan karakter ruas batang tanaman yang pendek dan susunan daun roset. Karakter tersebut dapat digunakan sebagai bahan seleksi untuk indukan unggul. Protokorm yang diiradiasi dengan dosis 45 Gy seluruhnya mengalami nekrosis dan mati.

Penelitian lanjutan sebaiknya dilakukan untuk menyeleksi secara lebih spesifik mutanmutan yang ada dan sudah mencapai kondisi mutan yang stabil.

\section{UCAPAN TERIMA KASIH}

Ucapan terima kasih disampaikan kepada PAIR-BATAN dan P2KTKR-LIPI, karena hasil penelitian ini merupakan sinergi kerja sama Pusat Unggulan Iptek antar kedua lembaga untuk menghasilkan varietas baru dari hasil iradiasi sinar gamma.

\section{DAFTAR PUSTAKA}

Afrasiab H, Iqbal J. 2010. In vitro techniques and mutagenesis for the genetic improvement of potato cvs. Desiree and Diamant. Pakistan Journal of Botany 42(3): 1629-1637.

Aloysius S, Purwantoro A, Dewi K, Semiarti E. 2017. Improvement of genetic variability in seedlings Spathoglottis plicata orchids through X-ray irradiation. Biodiversitas 18 (1): 20-27.

Aprilianti P, Ratnadewi D, Irawati. 2018. Enkapsulasi protokorm untuk konservasi jangka pendek Grammatophyllum speciosum Blume (Orchidaceae). Buletin Kebun Raya 21(1): 920.

Ariffin S, Mohamad A, Hassan AA, Ahmad Z, Nazir Basiran M. 2010. Flower morphology of Dendrobium Sonia mutants. Prosiding R \& D Seminar 2010, Agensi Nuklear Malaysia. Bangi.

Borzouei A, Kafi M, Khazaei H, Naseriyan B, Majdabadi A. 2010. Effect of gamma radiation on germination and physiological aspect of wheat (Triticum aestivum L.) seedling. Pakistan Journal of Botany 42(4): 2281-2290.

Chang C, Chen YC, Yen HF. 2005. Protokorm or rhizome? The morphology of seed germination in Cymbidium dayanum Reichb. Botanical Bulletin of Academia Sinica 46: 7174.

Dehgahi R, Joniyasa A. 2017. Gamma irradiationinduced variation in Dendrobium Sonia-28 orchid protokorm-like bodies (PROTOKORMs). Fungal Genomics \& Biology 7 (2): 151-161.

Gaswanto R, Syukur M, Purwoko BS, Hidayat SH. 2016. Induced mutation by gamma rays irradiation to increase chilli resistance to Begomovirus. Agrivita 38(1): 24-32.

Hayati D, Aisyah SI, Krisantini. 2016. Radiosensitivity levels of in vitro cultured Celosia cristata planlets by $\mathrm{Y}$-ray irradiation. Journal of Tropical Crop Science 3 (2): 61-65.

Handini E. 2019. Iradiasi akut dengan sinar gamma pada protokorm anggrek Dendrobium macrophyllum A. Richard dan Dendrobium undulatum M. A. Clem \& D. L. Jones. Buletin Kebun Raya 22(1): 13-20.

Hazekamp A. 2016. Evaluating the effects of gamma-irradiation for decontamination of medicinal cannabis. Frontiers in Pharmacology 7: 1-12.

Kovalchuk O, Burke P, Arkhipov A, Kuchma N, James SJ. 2003. Genome hypermethylation in Pinus silvestris of Chernobyl a mechanism for radiation adaptation. Mutation Research/ Fundamental and Molecular Mechanisms of Mutagenesis 529: 13-20.

Kovalchuk I, Abramov V, Pogribny I, Kovalchuk O. 2004. Molecular aspects of plant adaptation to life in the Chernobyl zone. Plant Physiology 135: 357- 363.

Lestari EP, Yunus A, Sugiyarto. 2018. Diversity induction of Dendrobium sylvanum orchid through in vitro irradiation of gamma ray. Biosaintifika 10(3): 691-697.

O’Byrne P. 1994. Lowland orchids of Papua New Guinea. SNP, Singapore.

Puspitaningtyas DM, Handini E. 2014. Penyimpanan biji anggrek Coelogyne spp. untuk konservasi ex situ. Buletin Kebun Raya 17(2): 101-112. 
Sasongko AB, Fatumi A, Indrianto A. 2016. The growth improvement of Grammatophyllum scriptum (Lindl.) Bl. in vitro plantlet using photoautotrophic micropropagation system. Indonesian Journal of Biotechnology 21(2): 109-116.

Schum A. 2003. Mutation breeding in ornamental: an efficient breeding method? Acta Horticulturae 612: 47-60.

Surya MI, Suranto H. 2006. Effect of gamma irradiation on the growth of sweet sorghum (Sorghum bicolor L.). Risalah Seminar IImiah Aplikasi Isotop dan Radiasi.

Suwarno A, Habibah NA, Herlina. 2013. Respon pertumbuhan planlet anggrek Phalaenopsis amabilis L. var. jawa candiochid akibat radiasi sinar gamma. Unnes Journal of Life Science 2 (2): 78-84

Tokuhara K, Mii M. 2001. Induction of embryonic callus and cell suspension culture from shoot tips excised from flower stalkbuds of Phalaenopsis (Orchidaceae). In Vitro Cellular Developmental Biology-Plant 37: 457-461.

Utami ESW, Purnobasuki H, Soedarti T, Hariyanto S. 2015. Asymbiotic seed germination and in vitro seedling development of Paphiopedilum liemianum Fowlie, an endangered terrestrial orchid in Northern Sumatra, Indonesia. Journal of Plant Sciences 10(1): 25-34.

Wang P, Zhang Y, Zhao L, Mo B, Luo T. 2017. Effect of gamma rays on Sophora daviidii and detection of DNA polymorphism through ISSR marker. BioMedResearch International 2017: 1-6.

Wijayani Y, Solichatun, Mudyantini W. 2007. Pertumbuhan tunas dan struktur anatomi Protokorm like body anggrek Grammatophyllum scriptum (Lindl.) Bl. dengan pemberian kinetin dan NAA. Bioteknologi 4(2): 33-40.

Xo DH, Luan LQ. 2017. In vitro mutagenesis of Cymbidium La bell "Anna Belle" by $\gamma$-rays irradiation and oligochitosan interaction. International Journal of Environment, Agriculture and Biotechnology 4: 15401550.

Zanzibar M, Megawati, Pujiastuti E, Sudrajat DJ. 2015. Iradiasi sinar gamma $\left({ }^{60} \mathrm{Co}\right)$ untuk meningkatkan perkecambahan dan pertumbuhan bibit tembesu (Fagraea fragrans Roxb.). Jurnal Penelitian Hutan Tanaman 12(3): 16-174. 